\title{
A LUTA PELO ESPAÇO NO CONTEXTO DO PROJETO PORTO MARAVILHA:
}

1 Agradecemos aos pareceristas pelas sugestões; à Ana Luiza Accioly Pereira, pela revisão ortográfica; e aos sujeitos que nos concederam as entrevistas e materiais necessários para as análises.

2 Parceria público-privada de $\mathrm{R} \$$ 7,6 bilhões (aproximadamente US\$ 2,0 bilhões, em 02/12/2015), alinhada ao modo neoliberal de pensar e produzir cidades, tendo como objetivo central revitalizar o espaço portuário carioca a fim de possibilitar a reprodução do capital. Esse objetivo tem sido alcançado por meio da dominação sobre os usos atuais daquele espaço, o que implica a construção e mobilização de distintas relações de poder e resistências, que possuem como centro a luta pelo espaço. É importante dizer que utilizamos o termo revitalização por ser este o vocábulo mais frequentemente empregado pela grande mídia e pelos discursos públicos. Revitalizar, em seu sentido estrito, significa trazer vida a um determinado espaço que estava morto, com o que, particularmente, não concordamos. Uma boa análise sobre o termo, confrontando-o com outros, como requalificação, renovação e reabilitação, pode ser encontrada em Duarte (2005).

\author{
NOVOS SUJEITOS E CONTRADIÇÓES ${ }^{1}$
}

\section{THE STRUGGLE FOR SPACE IN THE CONTEXT OF PORTO MARAVILHA:}

NEW SUBJETCS AND CONTRADICTIONS

\section{Letícia de Carvalho Giannella}

Instituto Brasileiro de Geografia e Estatística, Escola Nacional de Ciências Estatísticas, Rio de Janeiro, RJ, Brasil

R E S U M O : Ao mesmo tempo em que os promotores do Projeto Porto Maravilha se empenham em divulgar imagens de uma cidade devidamente asséptica e isenta de conflitos, observa-se que estes têm se intensificado na cidade do Rio de Janeiro nos últimos anos. $O$ artigo procura desvendar tais conflitos a partir do campo das resistências e das diversas formas de luta que têm sido construidas e mobilizadas atualmente, em especial no escopo do Fórum Comunitário do Porto, coletivo, formado em 2011, que atuou na denúncia de violaçóes de direitos das populaçóes afetadas pelo projeto e na articulação interinstitucional para a defesa de seus direitos. Buscamos submeter à análise os novos processos de mobilização, a construção de contrapoderes e as fissuras que se dão no cerne da produção do espaço, identificando também as contradiçôes internas à luta e apontando para a necessidade de abordagens teóricas que ajudem a compreender o mundo contemporâneo.

P A L A V R A S - C H A V E : Porto Maravilha; Fórum Comunitário do Porto; conflitos urbanos; luta pelo espaço; movimentos sociais.

Junho de 2009. Os jornais estampam uma fotografia em que o entáo presidente Lula, Sérgio Cabral, governador do Rio de Janeiro, e o prefeito da capital do estado, Eduardo Paes, aparecem em comunhão para celebrar a Operação Urbana Consorciada (OUC) da Regiáo do Porto do Rio de Janeiro, ordinariamente conhecida como Projeto Porto Maravilha².

Junho de 2013. Assistimos, perplexos, à ebulição da juventude brasileira, que se espraiou pelas ruas do país como poucas vezes em nossa história. A euforia que se espalhou pelo Brasil com a eleiçáo do país para sede da Copa do Mundo de 2014 e com a escolha do Rio de Janeiro para sede dos Jogos Olímpicos de 2016 não se sustentou. Rolnik (2013, p. 8) compreende "essas manifestaçôes como um terremoto [...] que fez emergir não uma, mas uma infinidade de agendas mal resolvidas, contradiçóes e paradoxos".

As insatisfações populares visibilizadas nas manifestações de 2013 puseram na pauta pública aquilo que, há tempos, diversos coletivos e pesquisadores já vinham alertando: as cidades brasileiras se tornaram mais fragmentadas, desiguais 
e excludentes com a reconfiguração das relaçóes entre capital, Estado e sociedade, desenhada desde os anos 1980-1990.

O Projeto Porto Maravilha, inserido nesse contexto, apresenta uma contradição fundamental: ao mesmo tempo em que seus promotores se apressam em divulgar imagens daquilo que se tornará uma cidade asséptica e isenta de antigos conflitos imagens centrais para a atração de investidores e de "usuários solventes" (VAINER, 2009 [2000]) -, assistimos ao agravamento dos mesmos conflitos nos últimos anos.

Este artigo é uma síntese de um dos eixos de uma pesquisa mais ampla (GIANNELLA, 2015) que intencionou compreender esses conflitos a partir de uma perspectiva teórica que partisse do materialismo histórico e dialético e dialogasse com o entendimento das relaçôes de poder na produção do espaço urbano. Os autores centrais para essa investigação foram Henri Lefebvre, David Harvey, Michel Foucault, John Holloway e, para tratar especificamente das novas formas de mobilização no contexto latino-americano, Raul Zibechi.

Neste texto, enfatizaremos, em particular, a dimensão das diversas formas de luta pelo espaço, configuradas no contexto de acirramento de conflitos. As lutas e sujeitos trazidos aqui derivam da nossa observação participante do/no Fórum Comunitário do Porto (FCP), coletivo formado em 2011 e que atuou na denúncia de violaçóes dos direitos das populaçôes afetadas pela intervenção do Porto Maravilha e na articulação interinstitucional para a defesa de seus direitos. É desse lugar que falamos, ainda que não nos posicionemos como representantes do coletivo ou de qualquer um dos sujeitos que o compuseram. Dessa forma, a metodologia da pesquisa tem como eixo central essa experiência. Contudo, recorremos também à análise de documentos produzidos coletivamente pelo FCP e/ou por organizaçóes que o formaram, bem como a entrevistas semiestruturadas com os sujeitos abordados ${ }^{3}$.

Buscaremos, aqui, responder às seguintes indagaçôes: (i) A partir de quais estratégias têm-se desenrolado as diversas formas de luta pelo espaço elencadas na investigação?; (ii) $\mathrm{O}$ que essas lutas evidenciam em termos de concepçôes sobre o urbano?; (iii) Quais sujeitos estão envolvidos nesse processo de luta e quais conquistas podem ser consideradas?; (iv) Quais limites e desafios se colocam para essas lutas e quais contradiçóes internas elas apresentam?

Vale ressaltar, de antemão, a importância de submeter à análise os novos processos de mobilização, de construção de contrapoderes e de fissuras ${ }^{4}$. Como aponta Raul Zibechi (2007; 2008), na América Latina, saltam aos olhos os novos movimentos sociais e as novas formas de luta. Esses movimentos - fluidos, flexíveis, abertos, não hierárquicos - lutam contra relaçôes de poder que se inscrevem no cotidiano. $\mathrm{O}$ espaço urbano, em especial, é lócus privilegiado de análise, uma vez que, de acordo com Zibechi, tais movimentos se constroem e mobilizam-se a partir da potência que existe no próprio processo de produção do espaço. Este é produzido, dialeticamente, como obra e produto, valor de uso e valor de troca, fazer concreto e trabalho abstrato. Assim, não se pode esperar o uso de um tempo longo para enfrentar o oponente. Falamos sobre a práxis urgente, sobre a luta pelo espaço, que, no limite, é a luta pela sobrevivência (HOLLOWAY, 2013).

Nas seçôes seguintes, procuramos, em um primeiro momento, apresentar a construção do processo de luta pelo espaço no contexto do Porto Maravilha, evidenciando quem são os seus distintos sujeitos, bem como quais estratégias, concepçôes sobre a cidade e o urbano e ações concretas estão em jogo 5 . Em um
3 Tais entrevistas foram realizadas entre abril e dezembro de 2014. Cumpre pontuar que a seleção dos sujeitos baseia-se, inevitavelmente, na nossa experiência no $F C P$, desde 2011, e, portanto, tem uma dimensão subjetiva. 0 fato de tais sujeitos estarem presentes aqui não quer dizer que outros sujeitos, situados em cada um dos segmentos analisados, não tenham contribuído, igualmente, para o processo estudado. Entre os sujeitos apresentados no quadro, não entrevistamos, devido a impossibilidades de diversas ordens, os representantes do Departamento de Serviço Social da Universidade do Estado do Rio de Janeiro (UERJ), da Comunidade Remanescente do Quilombo da Pedra do Sal e os moradores da Rua do Livramento, ainda que estes tenham sido entrevistados no contexto de elaboração do Relatório de Violações de Direitos e Reivindicações do FCP, em 2011, do qual participamos.

40 conceito de fissura é tomado do marxista heterodoxo John Holloway (2013), que considera a necessidade de, no mundo contemporâneo, procurar (e criar) processos sociais que estejam orientados na direção da subversão do trabalho abstrato em fazer, na dupla característica do trabalho, indo além da luta entre trabalho e capital. As fissuras se constroem no cotidiano, no tempo imediato; não abandonam o horizonte temporal mais largo para a transformação, ainda que não o priorizem.

5 Para um aprofundamento a respeito dos sujeitos no campo hegemônico da operação, ver Giannella (2015). 
segundo momento, apontamos as contradiçóes que essas lutas apresentam, em especial entre seus distintos sujeitos, ou seja, na escala dos micropoderes. Em resumo, intentamos evidenciar - tendo como referência empírica o FCP - a necessidade de construção de novas abordagens teóricas diante das novas mobilizaçôes sociais.

\section{O LUGAR DE ONDE FALAMOS: CONTEXTUALIZANDO O FÓRUM COMUNITÁRIO DO PORTO}

O Projeto Porto Maravilha foi lançado oficialmente em 23 de junho de 2009. Pouco depois, em março de 2010, realizou-se no Rio de Janeiro o 5 Fórum Urbano Mundial (FUM), promovido pelo programa das Naçóes Unidas para o Habitat (ONUHabitat). Na mesma semana, foi organizado, como contraponto ao FUM, o Fórum Social Urbano (FSU), com o objetivo de fazer com que a questáo urbana entrasse na pauta de discussóes a partir de uma perspectiva crítica e radical. Participando como ouvinte de tal evento, despertamo-nos para a investigação da temática deste artigo, um dos desdobramentos de uma pesquisa mais ampla.

Um dos interlocutores mais expressivos a respeito das contradiçóes do Porto Maravilha era o ex-vereador e atual deputado estadual Eliomar Coelho (PSOL), que tinha proposto diversas emendas parlamentares aos projetos de lei que estruturaram a operação - projetos estes aprovados às pressas na Câmara dos Vereadores, em 23 de novembro de 2009. Antes do FSU, a sua equipe e outros grupos tinham realizado algumas reunióes para debater o caso do Porto Maravilha, inclusive com o intuito de embasar a elaboração das emendas parlamentares; após o evento, foi organizada uma nova reuniáo ampliada com pesquisadores e moradores para traçar estratégias de mobilização.

Esse encontro foi sucedido por diversos outros, os quais contaram, entretanto, com poucos moradores da Zona Portuária. Em janeiro de 2011, o grupo foi convidado para participar de uma reunião comunitária que ocorreria no Centro Cultural José Bonifácio (CCJB), organizada por uma liderança local, frente à incipiente repercussão do projeto e aos primeiros relatos de ameaças de violaçôes de direitos. Tais ameaças se referiam aos moradores dos imóveis privados e abandonados da Rua do Livramento, no bairro da Gamboa. Do agrupamento daqueles que vinham se reunindo na Câmara, no decorrer do segundo semestre de 2010, com os moradores que se encontravam no centro cultural, formou-se o Fórum Comunitário do Porto (FCP).

Nas primeiras reuniōes, realizadas, em 2010, na Câmara dos Vereadores, o debate se centrou na operação, nas propostas e nos possíveis impactos. Como ainda não havia violaçôes de direitos efetivamente praticadas associadas à operação, a preocupação principal era a construçáo de estratégias que impedissem o andamento da intervenção tal como aparecia nos projetos de lei que a tinham criado. Desse modo, o coletivo tinha como objetivos centrais a elaboraçáo de um projeto alternativo e a divulgação ampla dos possíveis impactos do Porto Maravilha no cotidiano dos moradores da Zona Portuária, buscando desconstruir o discurso hegemônico.

Quando se formou o FCP e o grupo inicial passou a se reunir com os primeiros moradores ameaçados pelo Porto Maravilha no CCJB, a intenção de elaborar um projeto alternativo e de divulgar os possíveis impactos do projeto foi substituída pela constituição de um espaço onde se compilavam as denúncias de violaçóes de direitos 
na Zona Portuária e onde eram facilitadas articulaçóes institucionais voltadas à defesa desses direitos.

Logo, além de pesquisadores, militantes, representantes de mandatos parlamentares e moradores, os encontros seguintes do FCP contaram também com a presença de representantes da Defensoria Pública Geral do Estado do Rio de Janeiro (DPGE), do Ministério Público Federal (MPF) e, eventualmente, de representantes da Secretaria Municipal de Habitação (SMH) e da Companhia de Desenvolvimento Urbano da Região do Porto do Rio (CDURP), empresa de economia mista que administra o território no qual intervém a OUC. Pouco a pouco, o FCP ganhou reconhecimento dentro e fora do espaço portuário, passando a atrair novos sujeitos.

A dinâmica que se estabeleceu no coletivo, então, passou pela agregação de sujeitos com expectativas, alinhamentos e experiências distintas entre si. Ainda, o FCP surgiu devido a uma problemática específica, o que o difere de outros movimentos norteados por um projeto de longo prazo de transformação da sociedade. Essa característica tornou o FCP um coletivo que "dançou conforme a música"; isso implica dizer que, quando a problemática se apaziguava - mesmo considerando que, geralmente, esse apaziguamento se dava, de um lado, como resultado da luta e, de outro, como estratégia política dos sujeitos hegemônicos -, o coletivo, de certa forma, se esvaziava.

A resistência no contexto do $\mathrm{FCP}$ se deu à proporção que a intervenção se inscreveu no cotidiano daquele espaço, vide a relaçáo intrínseca que se estabeleceu entre o curso das obras e a chegada dos novos sujeitos ao FCP. A luta se iniciou com os moradores da Rua do Livramento (nos encontros do CCJB), justamente porque ali ocorreram os primeiros sinais de violaçóes. Quando as obras chegaram ao Morro da Providência, por sua vez, seus moradores passaram a frequentar as reunióes do FCP. E, mesmo no interior do Morro da Providência, inicialmente chegaram os moradores do Sessenta, que foram os primeiros a ter as suas casas marcadas pela SMH, junto dos moradores da Pedra Lisa, que começaram a ouvir rumores a respeito da remoção de todas as casas da localidade. Em seguida, chegaram os moradores dos edifícios da Ladeira do Barroso e da Ladeira do Faria, somados aos moradores do lado direito da escadaria (de quem sobe), por onde passaria, inicialmente, o plano inclinado. E, por fim, chegaram os moradores do lado esquerdo da escadaria (de quem sobe), acompanhando a mudança do projeto do plano inclinado. Os moradores cujas ameaças cessavam, com algumas exceçóes, deixavam de frequentar os encontros do FCP.

Hoje, o coletivo não está efetivamente ativo. Seus membros estáo relativamente dispersos, alguns voltados para a docência e à pesquisa, outros voltados para o trabalho em suas instituiçôes, outros, por sua vez, continuam exercendo sua atuação militante em outros coletivos; os moradores, cada vez em menor número, cansados, estão articulados diretamente com os órgáos de governo, em especial com a Defensoria Pública Geral do Estado (DPGE).

Não nos ocuparemos em fazer uma discussão profunda a respeito dos conflitos entre as distintas instituiçôes/organizaçôes que compuseram o FCP, pois esse esforço demandaria uma análise que não faz parte da nossa proposta. Não obstante, é importante identificar os distintos interesses, as estratégias e os alinhamentos políticoideológicos a fim de entendê-los como distintas formas de luta que possuem, no fundo, um objetivo comum. Estamos falando, dessa forma, mais de comunhão de lutas que de desagregação. É isso que queremos enfatizar, esperando que o exercício contribua para a valorização do papel cumprido por cada um dos sujeitos analisados. Mais do 
que apontar os conflitos de uma forma desagregadora, é interessante identificar que muitas das contradiçóes em questão eram históricas, existindo, portanto, diversas alternativas não consumadas e virtualidades não realizadas (LEFEBVRE, 2013 [1974]) que vieram à tona nesse momento de luta.

Uma das contradiçôes presentes no processo de luta receberá, porém, um pouco mais de atenção. Trata-se da já citada contradição entre os "de fora" e os "de dentro". Generalizando, há, por um lado, as instituiçôes/organizaçôes que costumam atuar de forma mais idealizada, apostando na formaçâo política dos moradores e no projeto global de transformação, enquanto, por outro, há os moradores, que, em boa medida, estão preocupados em garantir a sobrevivência física (HOLLOWAY, 2013). A luta pela sobrevivência, pela permanência em seus espaços de vida, é uma luta urgente, isto é, que não conta com um projeto de futuro.

$\mathrm{Na}$ próxima seção, apresentamos os principais sujeitos que compuseram, em algum momento, o FCP, suas distintas formas de luta e as contradições, a fim de respondermos às indagaçôes elencadas na introdução.

\section{SUJEITOS E CONTRADIÇÕES DA LUTA PELO ESPAÇO NO CONTEXTO DO PORTO MARAVILHA}

No quadro 1, agrupamos os sujeitos envolvidos no FCP nos seguintes segmentos de atividade: pesquisadores, mandatos parlamentares, organizaçôes sociais, organizaçôes culturais, movimentos de moradia, órgãos jurídicos, apoio técnico e, por fim, moradores. Em cada um desses segmentos, selecionamos aqueles sujeitos cuja participação na luta efetivou-se com intensidade - a partir do ponto de vista da nossa experiência, e, portanto, baseando-nos em um recorte subjetivo. No quadro, estão sintetizados os momentos em que os sujeitos se inscreveram no processo de luta, a relação entre eles e a Zona Portuária, os interesses, as principais ações empreendidas, as alianças formadas, a concepção de espaço que cada um incorporou e os alinhamentos político-ideológicos.

Iniciaremos nossa análise observando o segmento dos moradores, uma vez que estamos interessados em investigar as contradiçóes que se estabeleceram entre esse grupo e as organizaçóes/instituiçóes. Ao procurarmos destrinchar o papel desempenhado pelos moradores na luta pelo espaço portuário, os demais segmentos virão à tona, inevitavelmente, pois, conforme já dissemos, trata-se da análise de um coletivo fluido, no qual as açôes e estratégias dos sujeitos estão imbricadas, pendendo ora para a necessidade urgente de lutar pela própria sobrevivência, ora para a construção de um horizonte global de transformação da sociedade, e, muitas vezes, instaurando contradiçôes entre essas duas tendências.

Tanto Foucault (2008 [1977-1978]; 2010 [1975]; 2011 [1979]) quanto Lefebvre (1973; 2008 [1970]; 2013 [1974]) acreditam, cada um com suas especificidades, que as relaçôes capitalistas se reproduzem, para além do plano econômico, na constituição de um cotidiano programado para esse fim e por meio da produçáo do espaço urbano. As resistências de Foucault (nossa análise parte das resistências, que são a outra ponta das relações de poder nas mais diversas escalas, e por isso a menção ao autor), assim, estariam mais ou menos no campo da utopia urbana de Lefebvre, utopia que compreende o espaço efetivamente apropriado - a potência do urbano 
L E T I C I A D E C A R V A L H O G I A N N E L L A

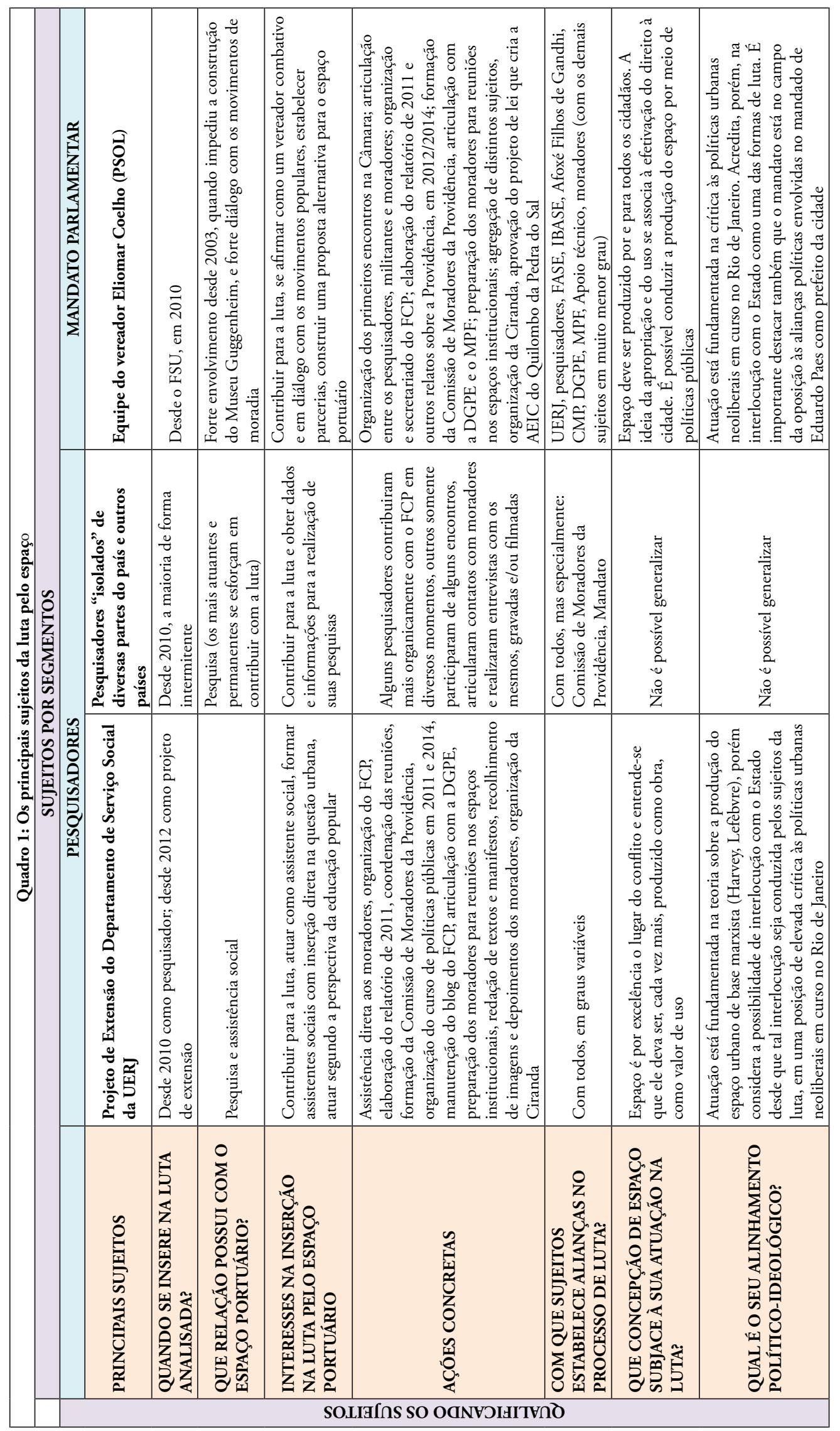


A L U T A P E L O E S P A Ç O $\mathrm{N}$ O C C O N T E X T O

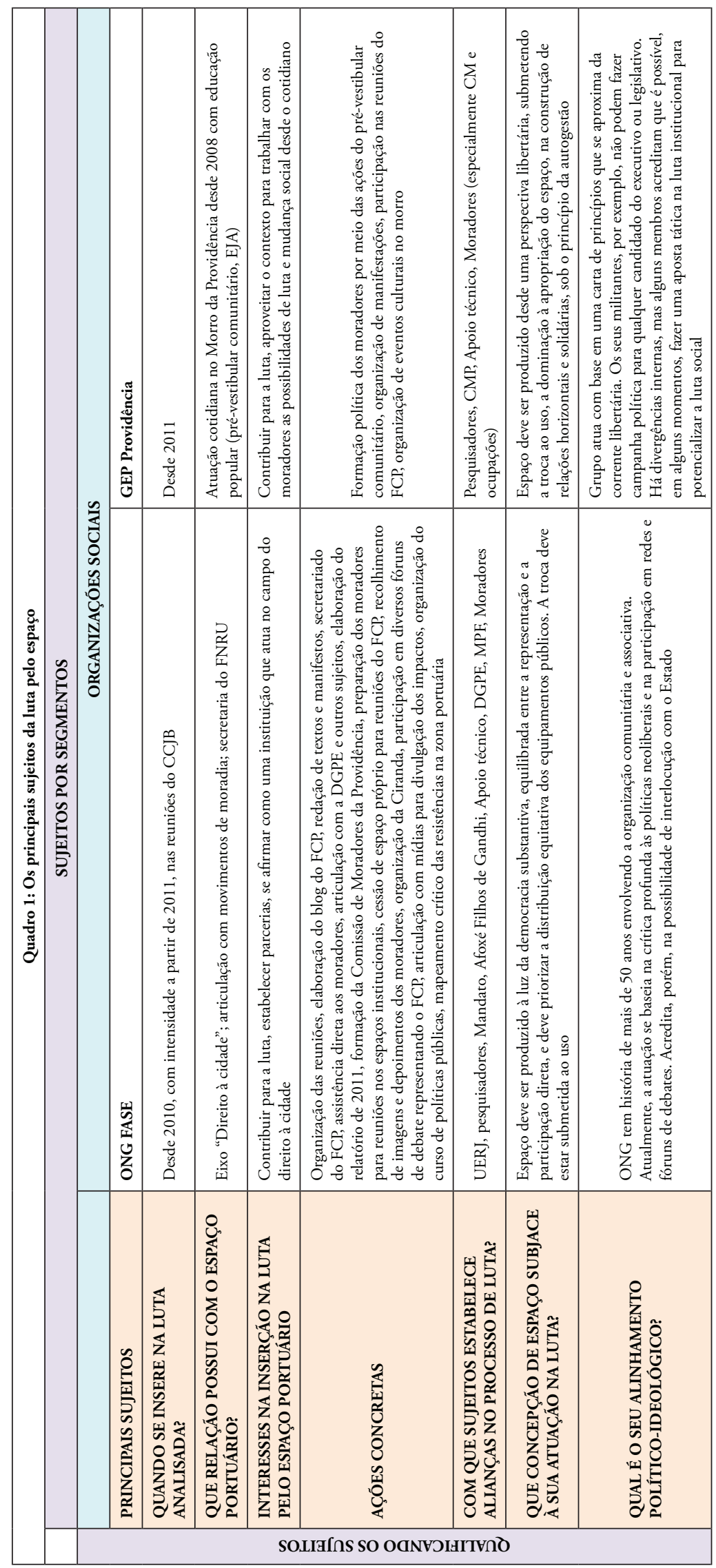


L E T I C I A D E C A R V A L H O G I A N N E L L A

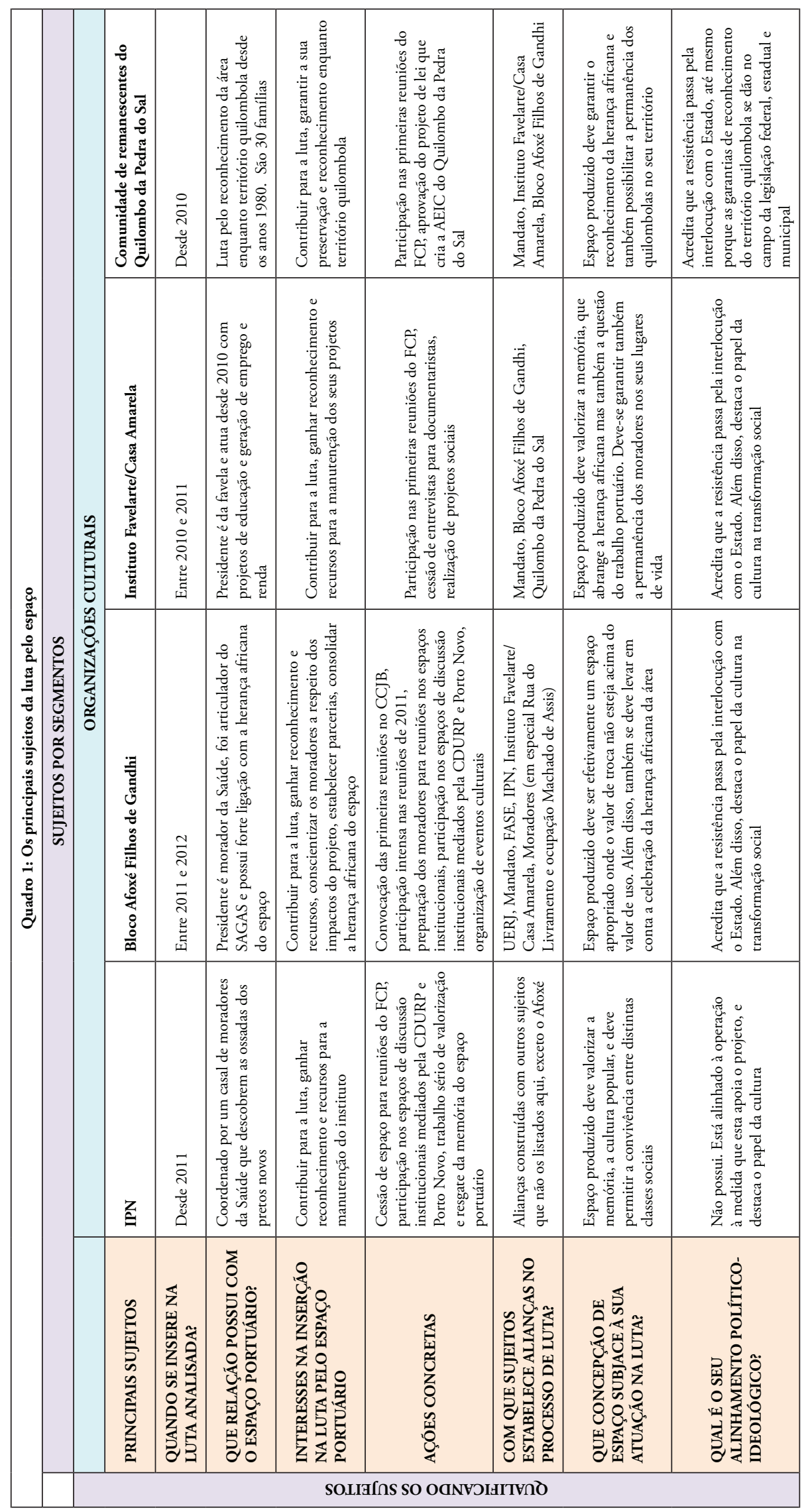


A L U T A P E L O E S P A Ç O $\mathrm{N}$ O C C O N T E X T O

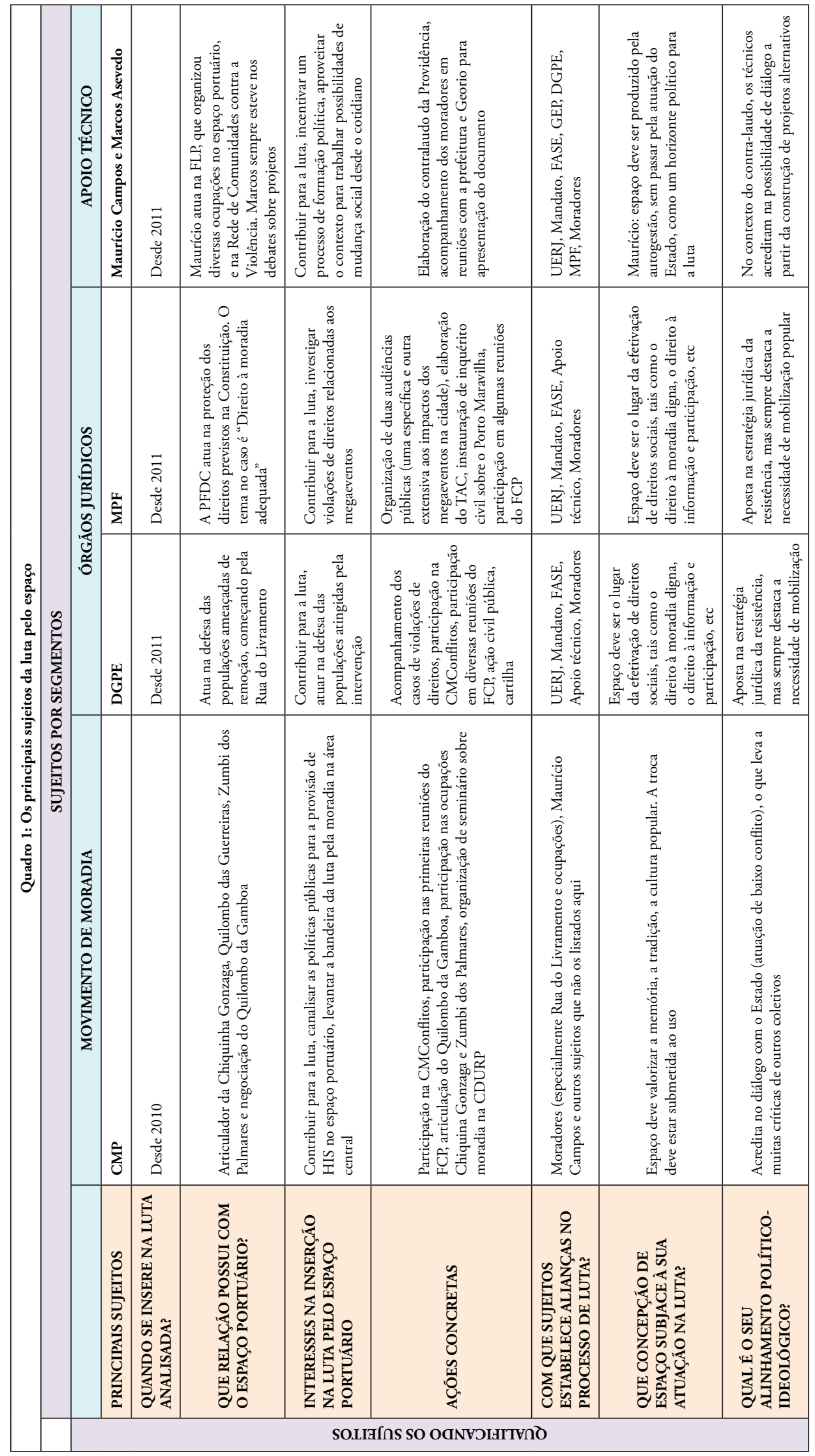


L E T I C I A D E C A R V A L H O G I A N N E L L A

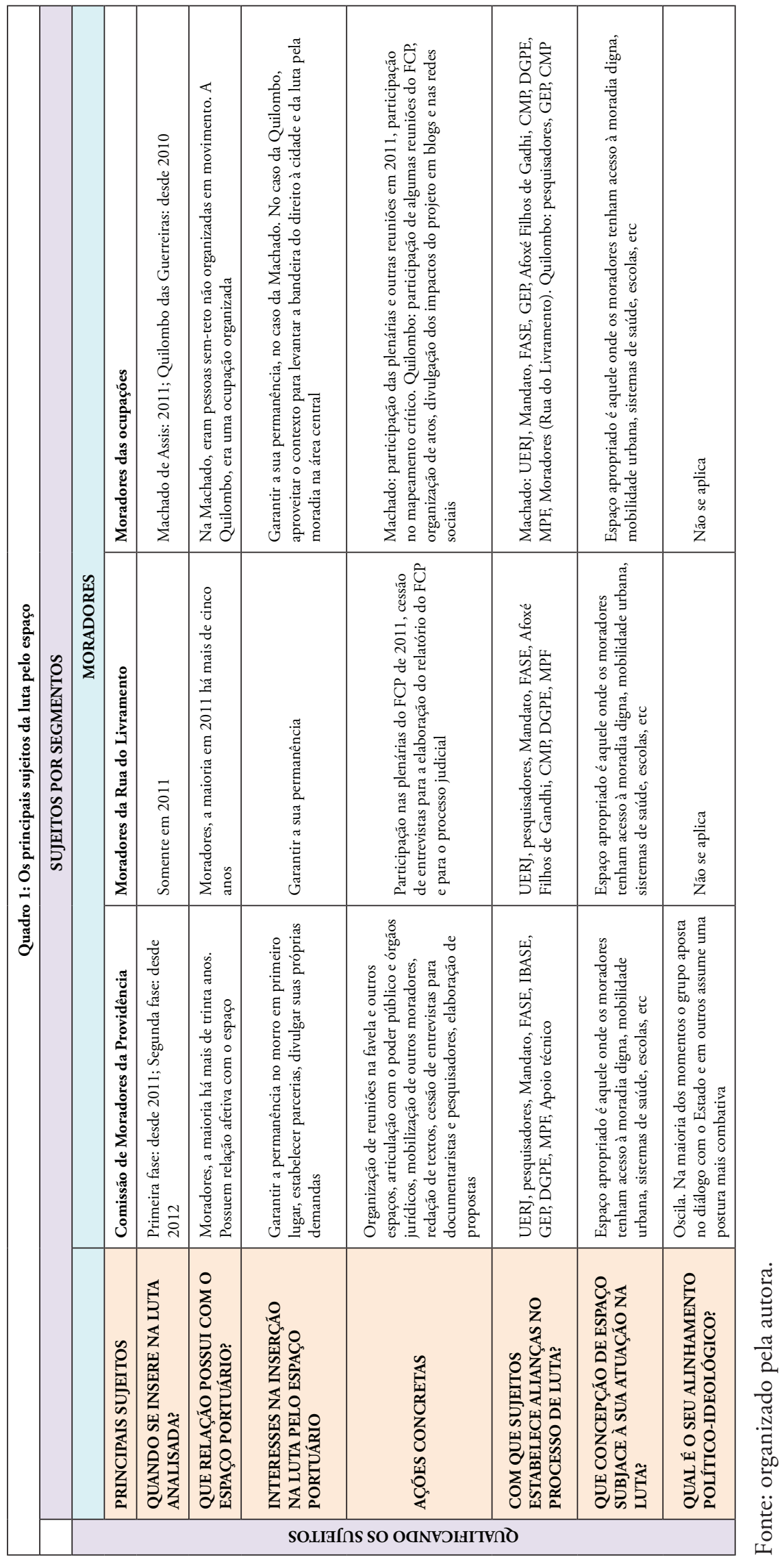


6 Para uma problematização da relação entre Lefebvre e Foucault, ver: Giannella (2015). como valor de uso presente no processo de produção e reprodução do espaço. Ainda que Foucault considere que as relaçóes de poder ultrapassam as relaçôes de produção e Lefebvre aponte que o capitalismo se mantém por meio da reprodução das relaçôes de produção, a produçáo é usada, neste artigo, em seu sentido abrangente - produção como obra - e está inscrita no cotidiano ${ }^{6}$.

Ao trazermos esses autores para a análise - junto de Holloway (2013), Zibechi (2006; 2007; 2008) e De Certeau (2012 [1990]) -, levantamos a hipótese de que a contradição fundamental existente entre moradores do espaço portuário, de um lado, e organizaçôes/instituiçôes do FCP, de outro, está fundada na falta de percepção de que há distintas formas de luta, as quais apresentam, porém, como horizonte, a luta pelo espaço, a luta do uso contra a troca, da apropriação contra a dominação, da obra contra o produto, do fazer concreto contra o trabalho abstrato. É preciso entender, ainda, que a luta empreendida pelos moradores se traduz, muitas vezes, na luta pela própria vida.

As concepções de espaço dos sujeitos envolvidos com a luta divergem entre si em alguns pontos, mas convergem para a ideia de que a luta pelo espaço deve se dar até que o uso não esteja mais submetido à troca. Ratificamos, ainda, que considerar a luta pelo espaço é uma forma de colocar em tela justamente as contradiçóes que náo se esgotam no conflito de classes.

Assim, de início, é necessário dizer que as favelas e as ocupações urbanas são, por si só, espaços de resistência, o que Lefebvre, de certa forma, já dizia nos anos 1970. A luta pelo espaço na favela é uma luta desde sempre cotidiana, independente da chegada de projetos de intervenção urbana nos moldes do Porto Maravilha ou do Morar Carioca. Viver na favela é transgredir e resistir, cotidianamente. É aprender a lidar com o preconceito, com os estigmas, com a violência, institucional ou não, física ou simbólica, com a vigilância cada vez mais opressora, com a falta de saneamento básico, com o lixo na porta de casa e, claro, com as pragas urbanas associadas a ele, com a falta de água ou com a necessidade de carregar baldes de água por quilômetros, com a falta de mobilidade, enfim, com tensões e constrangimentos cotidianos de toda ordem. Não obstante, viver na favela é também viver em comunidade, para a qual a palavra "vizinhança" possui um significado especial: viver com solidariedade; com mais liberdade do que em muitos enclaves territoriais urbanos. Viver na favela é viver com criatividade, com festas, com regras próprias (tácitas ou explícitas); é viver lutando e tornar a luta a essência da própria vida.

Os moradores da favela da Providência - e de todas as outras periferias urbanas do mundo - são, nesse sentido, lutadores. Todos. Sempre. Portanto, quando uma intervenção como o Porto Maravilha se inscreve no espaço, é com um grupo de lutadores que ela se defronta.

Apesar disso, vivemos hoje um alto grau de fragmentação, de despolitização e individualismo, movido pelo ideário neoliberal, que acaba tendo influência fundamental na conformação das relações de poder nesses espaços. Somadas a esse fator, encontram-se as contradiçóes produzidas no próprio processo histórico de produção espacial.

Esse é, grosso modo, o cenário geral a partir do qual se desenvolve a luta pelo espaço aqui estudada. De um lado, vemos no quadro quais são as instituiçóes/ organizaçôes nela presentes, seus interesses, as estratégias e os alinhamentos políticoideológicos. As lutas, no campo das resistências cotidianas, podem ser traduzidas na 
luta pela vida, que, estrategicamente, em determinados momentos se institucionaliza e, em outros, não, comportando, assim, contradiçôes. Essa luta, dado o exposto, está imersa em um quadro complexo de relaçóes sociais que não podem ser reduzidas à dicotomia instituição-morador.

O segmento dos moradores que aparece no quadro apresenta três grupos principais: os moradores que formaram a Comissáo de Moradores da Providência ${ }^{7}$ os da Rua do Livramento, que participaram ativamente no início do FCP, tendo um papel crucial para a própria existência do coletivo; e, por fim, os moradores das principais ocupaçóes que já existiam no espaço portuário carioca e que dialogaram com o FCP, a saber, a Machado de Assis, situada na Rua do Livramento, e a Quilombo das Guerreiras, localizada na Avenida Francisco Bicalho. Iniciemos a análise a partir do último grupo.

Já foram publicadas muitas pesquisas a respeito das ocupaçóes do espaço portuário; neste texto, o que buscamos ressaltar - sem ineditismo, é importante dizer - é o caráter de resistência e luta que essas ocupaçóes comportam. A luta pelo espaço no contexto das ocupações urbanas é constituída por uma mescla de táticas e estratégias (DE CERTEAU, 2012 [1990]). Muitos dos trabalhadores que nela se engajam estão lutando taticamente pela própria sobrevivência no horizonte temporal da emergência, isto é, por aquilo que é urgente. Não há projeto global; não há a totalização do adversário em um espaço distinto, opera-se "golpe por golpe", dia após dia. Morar é urgente. Por esse prisma, as ocupações são vistas como fissuras (HOLLOWAY, 2013), com um forte caráter espacial.

É necessário ressaltar, ainda, que a existência de imóveis vazios, de um lado, e a ocupação deles por movimentos organizados ou não, de outro, fazem parte de um mesmo processo de produção do espaço. A competição capitalista leva à superacumulaçáo, que, por sua vez, leva à mudança do fluxo de capital do circuito primário para o secundário, processo que, todavia, apresenta um limite que implica a desvalorização periódica e estratégica de determinadas porçóes do espaço. Esses espaços, por outro lado, estão implicados na capacidade do capital de se apropriar da renda. Novos valores de uso são criados, e os imóveis que antes estavam vazios - mas não abandonados, uma vez que tal condição é estratégica - inserem-se novamente no circuito da troca. A renda, assim, é determinada relacionalmente, com as expectativas futuras incorporadas no cálculo (HARVEY, 1980 [1973]). O capital não pode deixar que as pessoas subvertam a troca, apropriando-se desses espaços simplesmente como valor de uso. Logo, quando um imóvel é ocupado, seu proprietário (Estado ou proprietário privado), ao perceber que existe um movimento do capital - conduzido por uma aliança entre fraçóes de classe e Estado - que prevê ali a criaçáo de novos valores de uso, que, por sua vez, estarão submetidos à troca, promove a reintegração de posse, mesmo que a função social da propriedade não seja cumprida depois desse processo.

No caso do espaço portuário, a situação é mais grave, porque terrenos públicos que deveriam ser, prioritariamente, destinados à habitação social estão sendo repassados ao capital privado por meio de um mecanismo que envolve a reproduçáo do capital na esfera financeira, concentrando-os nas mãos de poucas empreiteiras, incorporadoras e financeiras. O caso da Ocupação Zumbi dos Palmares é exemplar. Trata-se de uma ocupaçáo com cerca de 130 famílias que foi desmantelada ainda em meados de 2010. As famílias ocupavam um edifício situado na Rua Venezuela, pertencente ao Instituto Nacional de Seguridade Social (INSS), e, até o momento, já em 2015, o edifício encontra-se vazio e sem uso.
7 Essa comissão teve duas fases distintas, as quais acompanharam, de certa forma, o curso dos projetos no morro. 
A dialética valor de uso/valor de troca está sempre presente, e a luta se dá no sentido de deslocar essa relação até o ponto em que a troca esteja completamente submetida ao uso. Os princípios das ocupaçôes urbanas, bem como a concepção de espaço que elas envolvem passam por essa questão. A luta urgente, que, no limite, é a luta pela vida, constituída por fissuras, é a luta do uso contra a troca. Assim, com os aportes teóricos de Lefebvre, vemos que o próprio processo de produção do espaço comporta, em si, a luta, na medida em que a produção é entendida, dialeticamente, como produto e obra.

A Ocupação Machado de Assis funcionava em um edifício da multinacional Unilever, vazio há mais de 20 anos. Em 2008, cerca de 80 famílias se instalaram ali e conseguiram rapidamente aprovar um projeto de reabilitação do edifício e de destinação dele para Habitação de Interesse Social (HIS). Tratava-se, em sua maioria, de ex-moradores de rua e trabalhadores informais do centro da cidade. Entretanto, com a chegada do Porto Maravilha, a estratégia da prefeitura mudou, e foi feita a reintegraçáo de posse.

Naquele momento, todavia, a ocupação já contava com mais de 200 famílias e diversas problemáticas tinham vindo à tona, entre elas a entrada de sujeitos ligados às atividades ilícitas de venda de drogas. Essas contradiçôes - geralmente apropriadas pelo discurso hegemônico para deslegitimar as fissuras do capitalismo, como a existência de interesses ilícitos em jogo, a bandidagem etc. - são, na realidade, parte da luta cotidiana pelo espaço, dado que se trata da luta pela própria vida a partir de meios conhecidos, na maior parte dos casos, pelas pessoas. E mais: o agravamento dessas contradiçôes geralmente ocorre quando a resolução da questão e a construção de unidades de HIS para os moradores das ocupaçóes se arrastam no tempo. Por fim, essas ocupaçôes são exemplos de novas formas de se movimentar, para as quais não existem manuais ou diretrizes claras; elas são espaços que tentam se organizar minimamente, de forma flexível, polifuncional, o que pode levar, em contrapartida, à configuração de realidades contraditórias.

Trazendo Raul Zibechi (2008) para a análise, é visível que esses movimentos tomam como ponto de partida o que já existe na vida cotidiana. A capacidade que as pessoas têm, por exemplo, de fazer ligaçôes de luz e de água é uma experiência que se constrói cotidianamente e que está relacionada à luta diária pela vida. É possível considerar, igualmente, que essas ocupaçóes são desvios (LEFEBVRE, 2013 [1974]) que provisoriamente apontam para outras formas de conceber o espaço e de nele viver.

Nessas ocupaçôes, há grupos de trabalhadores sem-teto ao lado de militantes diversos, de pesquisadores etc. Elas são espaços, como o FCP, compostos por diversos interesses, estratégias e alinhamentos político-ideológicos. Há que considerar, ademais, que existem forças e constrangimentos que estão situados em outras escalas, acima do espaço confinado da ocupação, os quais fazem com que as contradiçóes que existem desde sempre aflorem em determinados momentos, tendo como consequência a desagregação.

Os imóveis ocupados da Rua do Livramento (vizinhos ao edifício da Unilever) apresentam situaçôes próximas às das ocupaçôes de imóveis abandonados supracitadas, porém com a diferença de que não há movimentos de moradia envolvidos no processo. São imóveis privados, abandonados há décadas, que foram sendo ocupados por famílias de forma menos planejada e mais espontânea do que a Machado de Assis e, principalmente, a Quilombo das Guerreiras. 
A destinação desses imóveis, após a remoção dos seus moradores, em finais de 2011, é, até o momento, desconhecida. Muitos deles se encontram, atualmente, com as portas e janelas fechadas com tijolos e cimento para impedir novas ocupaçóes; outros, por sua vez, foram novamente ocupados.

A luta dos moradores desses imóveis é uma luta essencialmente inscrita no cotidiano, tal como a dos moradores das favelas. Nesse sentido, é importante fazer uma distinção entre esse grupo e aquele das ocupaçôes organizadas por movimentos de moradia, que contam com projetos de longo prazo, horizontes políticos e alinhamentos ideológicos claros, além de se delimitarem como um componente central da luta pela moradia. Os moradores da Rua do Livramento, justamente pela ausência de tais elementos, podem ser caracterizados como um grupo mais suscetível a violaçóes de direitos, o que pode explicar o fato de terem sido os primeiros ameaçados e removidos de toda a área portuária, no final de 2011.

Partimos agora desses casos para abordar os sujeitos que acompanhamos mais de perto ao longo de todo o processo: os moradores do Morro da Providência. Consideramos, primeiramente, que a luta desses moradores é uma luta cotidiana pela própria sobrevivência. Inserimos essa luta no campo de uma luta mais abrangente: a luta pelo espaço portuário no contexto do Porto Maravilha. Nesse processo, novas táticas e estratégias foram criadas e novas relaçôes de poder foram estabelecidas e/ou mobilizadas.

A luta desses moradores no âmbito do FCP partiu da marcação das casas pela prefeitura. Sentindo que a própria sobrevivência, atrelada à permanência em seus espaços de vida, encontrava-se ameaçada, eles buscaram interlocutores e parceiros que pudessem contribuir para visibilizar o problema e articular soluçóes. Quando chegaram aos primeiros encontros do FCP, depararam-se com uma diversidade de posicionamentos político-ideológicos e de debates a respeito de distintas estratégias de ação, enquanto o que eles buscavam era a garantia da permanência em seus espaços de vida e da sobrevivência. Dessa forma, na dialética morador/organizaçóes, construiu-se um tipo de movimento que, intrinsecamente, comportava tensôes e contradiçôes.

A declaraçáo de uma moradora da Ladeira do Barroso explicita o objetivo central da luta cotidiana: "Mas eu vou falar outra coisa pra você. É... O que a gente da Providência quer é todos nós permanecermos dentro das nossas casas, sabia?” (Entrevista concedida por moradora da Ladeira do Barroso, em maio de 2014). Podese dizer que a luta desses moradores é permanente e cotidiana, mas a articulação entre ela e outras formas de luta, inclusive aquelas que eles mesmos assumiram no processo, deu-se a partir do momento em que surgiu uma ameaça específica e pontual. Em relação a esse aspecto, Zibechi (2008) afirma que os novos movimentos sociais seriam mais voltados a demandas específicas que a horizontes de transformação total da sociedade, o que fica patente ao observar a experiência do FCP.

$\mathrm{O}$ fato de os moradores se aproximarem da luta somente quando se sentiam pessoalmente ameaçados gerou conflitos dentro da própria favela. Alguns moradores acusaram outros de oportunismo ou de falta de coletividade. É possível que essa suposta falta de coletividade tenha-se dado em função, de um lado, do baixo grau de politização dos atuais espaços populares e, de outro, das relaçôes de poder que se estabelecem em todas as escalas e reproduzem o ideário neoliberal da competitividade, do individualismo e da satisfação pelo consumo ${ }^{8}$.
8 Vale ressaltar que uma das ações do Projeto Porto Maravilha é o Porto Cidadão, que se traduz em uma estratégia de promoção do empreendedorismo na região. São processos como estes que criam uma imagem de inclusão e, ao mesmo tempo, resultam na fragmentação e despolitização dos moradores. 
De qualquer modo, o processo de marcação das casas plantou medo e desconfiança, acabando por levar os moradores à luta em outros campos que não o das táticas de transgressão e resistência cotidianas.

Assim, os moradores do Sessenta, da Pedra Lisa e da escadaria compareceram aos encontros do FCP e encaminharam, por orientaçáo do MPF, a elaboração do Relatório de Violação de Direitos e Reivindicações. Foi aí que as suas lutas cotidianas passaram a se articular à luta contra as remoçôes. A luta se instalou justamente no contexto das ameaças à sobrevivência das pessoas:

Minha casa tá marcada, mas eu não vou sair da minha casa. Eu não vou sair. Eles acham que vão encontrar barro mole, mas comigo eles vão encontrar barro duro, porque eu passei necessidade pra mim levantar minha casa do chão (Entrevista concedida por moradora do Sessenta, em maio de 2011).

É possível lembrar novamente de Zibechi (2007), que constata que as periferias urbanas, especialmente as latino-americanas, são uma das fraturas mais importantes do capitalismo no mundo contemporâneo, justamente pelo fato de, nesses espaços, a terra, a casa e o bairro autoconstruídos serem sentidos como valores de uso, e não como valores de troca. A luta, no limite, é a luta pela própria vida.

Porque se tira a tua família, a tua casa, te mata, mata a tua cultura, mata a tua vida. Por que que eles vieram fazer isso com a gente aqui? Aqui só tem gente pobre e miserável, cara. É mesmo! Eu vejo os dois lados. Hoje, hoje eu acho que náo é nem bom conhecer o outro lado. A maioria aqui não conhece o lado do rico. Você vê que isso aqui é uma senzala aberta. Desculpa. [...] Eu acho que a maior luta que a gente tem é a nossa vida, a gente aprender a lidar com o próximo. Eu acho que a maior luta da vida eu já tinha dentro de mim e náo sabia (Entrevista concedida por moradora da Escadaria em novembro de 2014, grifo nosso).

Frente a essas ameaças, que são o acirramento das contradiçôes no processo de produção do espaço urbano, os moradores deslocaram as lutas cotidianas para outras escalas. A dimensão cotidiana da luta, assim, articulou-se a uma luta de dimensão mais organizativa.

Ao considerar a dimensão do cotidiano na produção do espaço urbano, Lefebvre assinala que quem faz a revolução são homens e mulheres comuns, o que significa, conforme ele mostra, um deslocamento das lutas do chão das fábricas para o espaço urbano. Para Holloway (2013), tal revoluçáo já acontece, está aí, apresenta-se como fissuras, normalmente, imperceptíveis, construídas à medida que novas relaçóes sociais, horizontais e solidárias, são efetivadas.

Quando a Praça Américo Brum foi fechada para dar início à construção do teleférico, os moradores fizeram cartazes com dizeres como "não queremos teleférico", "a praça é do povo", "nossa cultura é nosso povo" etc., e foram para a rua impedir o andamento da obra, junto dos representantes de organizaçóes/instituiçóes do FCP. Ainda que a ação não tenha impedido o fechamento da praça, a articulação da luta organizada pelos moradores com a luta no campo das organizaçôes/instituiçôes contribuiu para a ampla divulgação do ocorrido, atraindo diversos jornalistas e militantes de mídias alternativas e transformando o acontecimento em um fato político. 
Foi naquele contexto que instituiçóes/organizaçóes do FCP se reuniram com alguns moradores para começar a pensar a articulação de uma comissão de representantes de moradores por área. A ideia era que o processo começasse a tomar corpo a partir dos próprios moradores, para que eles se mobilizassem e se organizassem independentemente da assistência direta do FCP, e, assim, construíssem um processo autônomo em meio a tantos desafios cotidianos.

Segundo alguns entrevistados, os participantes da primeira fase da comissão de moradores tinham, em geral, interesses próprios que suplantavam os interesses coletivos:

Pessoal tá acostumado a participar dessas coisas, mais “toma lá dá cá". Trocar, eu quebro o galho de vocês, mas eu quero um retorno. Então, a preocupação, [...] a preocupação da gente não era essa. A nossa preocupação não era essa. A nossa preocupação era num sentido mais geral, não tem nada a ver de ficar trocando favor por favor (Entrevista concedida por morador da Ladeira do Livramento, em maio de 2014).

$\mathrm{Na}$ realidade, com a luta que se inscreve no cotidiano, no processo de produção do espaço, pode-se dizer que havia, em todo caso, a luta por interesses particulares. Os moradores que participaram da luta, no limite, estavam lutando pela própria sobrevivência. O questionamento se deu quando essa luta, para além da sobrevivência, atendia a interesses particulares que passavam pela possibilidade de acumular capital em um contexto de extrema fragilidade econômica.

Referente às contradiçóes entre moradores, de um lado, e organizaçóes/ instituiçóes que apoiavam a luta, de outro, deve-se levar em consideração que o contexto vivido pelos moradores passava por constrangimentos, pressóes e relaçóes de poder de toda ordem. Com efeito, eram poucos os que verdadeiramente se engajavam na luta, de modo que esses poucos acabavam concentrando as pressóes que vinham de diversos sujeitos, como a SMH, a Concessionária Rio Faz' a Unidade de Polícia Pacificadora (UPP), a Associação de Moradores, a CDURP, as organizaçóes de venda de drogas ilícitas, as pressôes financeiras, o contexto de competição e individualismo desenfreados. Enfim, tratava-se de uma complexidade de relaçóes que deve ser levada em consideração.

No contexto de desagregação da Comissão de Mediação de Conflitos (CMConflitos) - formada em 2011 e composta por diversas instituiçóes, incluindo representantes da prefeitura, mas desfeita rapidamente -, a primeira comissão de moradores foi se esvaziando pouco a pouco. Algumas das principais lideranças que se constituíram no processo de construção da primeira comissão passaram a ser atendidas, de forma não transparente, pelo poder público, representado, no caso, pela SMH e pela CDURP. E o FCP continuou atuando especialmente na articulação direta com a DPGE.

Nesse meio tempo, muitas demoliçóes e remoçóes aconteceram; foram organizados reunióes, encontros, seminários e diversas tentativas de reestruturação do FCP. Em 2012, o FCP organizou um encontro em que compareceram diversos moradores de áreas do morro que náo tinham qualquer relação nem com o FCP, nem com a primeira fase da Comissáo de Moradores. O comparecimento em peso de moradores da Providência mostrou que as remoçóes estavam avançando. Quando foi anunciada a mudança de lado no projeto do plano inclinado, os moradores de casas

9 Responsável pela execução das obras no Morro da Providência. 
10 Evento paralelo à Rio+20, organizado por diversos coletivos e movimentos sociais em contraponto às discussões do evento oficial, que teria, segundo os organizadores da Cúpula dos Povos, um caráter mais conservador. situadas no lado esquerdo (de quem sobe) passaram a se preocupar com a questão, sendo precursores de uma mobilização que resultou na paralisação das obras por meio de uma Ação Civil Pública (ACP) ocorrida no final do mesmo ano. Foi formada, assim, naquela reunião, uma segunda fase da Comissão de Moradores da Providência, que até hoje se encontra relativamente ativa. É importante destacar também que essa nova comissão se consolidou em meio ao processo de organização da Ciranda da Resistência, atividade cultural e política realizada na Cúpula dos Povos ${ }^{10}$, em junho de 2012, no Instituto Central do Povo (ICP)

A partir de entâo, pouco a pouco, a nova Comissão de Moradores foi construindo um processo de aquisiçáa de autonomia, e o espaço do FCP, que era o espaço fundamental de mediação e articulação institucional na área portuária, e em especial no Morro da Providência, passou a ter o seu sentido questionado. Os moradores passaram a se articular diretamente com os órgãos jurídicos de defesa e também com outras organizaçôes/instituiçôes, sendo a mais expressiva delas o Grupo de Educação Popular (GEP) (Quadro 1). As contradiçóes entre moradores e demais sujeitos que compunham o FCP vieram à tona, e a Comissão de Moradores começou a se reunir por si só e com outros sujeitos, sem demandar a presença do coletivo.

$\mathrm{Na}$ realidade, com a delimitação, cada vez mais clara, do grupo que compunha o FCP, de um lado, e da Comissão de Moradores, de outro - separação que não havia antes, sendo a comissão entendida como um dos sujeitos componentes do FCP -, o próprio perfil do FCP foi redefinido. O coletivo passou a concentrar cada vez mais pesquisadores, além do mandato parlamentar, que o acompanhava desde o início, e da Federação de Órgãos para Assistência Social e Educacional (FASE). A forte presença de pessoas da academia pôs em pauta uma das contradiçóes entre os dois grupos:

Começou aquela... Só que a comissão daquela época era com um pessoal que eu não tinha certa... Quer dizer, as pessoas não tinham maturidade política. [...] Mas teve um período que, quando reformulou a comissão, que reformulou outras cabeças, que eram pessoas mais seguras, que tinham mais produçôes, isso aí começou a cobrar algumas coisas do Fórum. A comissão, ela começou a perceber, pela minha visão particular, aqui, a questáo da remoção, dessa resistência, isso era uma coisa muito séria, a gente estava brigando em função de dez mil moradores. Quer contribuir? Contribui participando, mas não direcionando. Então eu sempre coloquei isso, eu ficaria muito triste se, a partir do momento que existisse essa participaçấo... e as pessoas estivessem usando a situação séria que está acontecendo para outros fins, não tem sentido. Não tem sentido você pegar uma situação, citando exemplo, pegar isso e transformar isso numa exposição, numa projeção de um seminário a favor (Entrevista concedida por morador da Ladeira do Livramento em maio de 2014).

O clímax da tensão entre esses dois blocos se deu em novembro de 2013, quando os moradores organizaram, junto de parceiros para além dos grupos que compunham o FCP - o que demonstra a autonomia e as articulaçóes diretas com sujeitos diversos -, uma manifestação que partiria do Cruzeiro e desceria para a "parte plana" do espaço portuário, pela Ladeira do Faria. Falando muito brevemente sobre esse acontecimento, é importante demarcar, em primeiro lugar, o contexto em que ele é pensado, contexto efervescente em decorrência das chamadas "Jornadas de Junho", quando diversos jovens passaram a se manifestar segundo as táticas black blocs. A complexidade envolvida nesse dia é representativa das inúmeras pressóes e relações de 
poder com as quais os moradores necessitavam lidar na luta cotidiana. Espalhou-se pelo morro o boato de que a comissão estaria preparando um ato com organizaçóes que agiam conforme as táticas black blocs, razão pela qual diversos sujeitos começaram a pressionar os moradores. A maioria dos presentes era de fora da favela e não conhecia a complexidade das múltiplas relaçóes de poder que estavam em jogo naquele espaço, o que gerou tensôes consideráveis.

A partir daí, ainda ocorreram novos encontros do FCP e da Comissão de Moradores, mas o desgaste das contradiçôes que, pouco a pouco, vieram à tona, a aquisiçáo progressiva de autonomia por parte dos moradores - um dos objetivos do FCP, desde o início, inclusive - e a "aquietação" da luta por meio da permanência da liminar que mantém as obras paralisadas até os dias atuais levaram ao espaçamento entre as reuniôes, até o ponto em que o FCP, de certa forma, saiu de cena. Todavia, as contradições são, muitas vezes, apagadas do processo de valorização da luta, conforme podemos ver nestas declaraçóes de moradores a respeito da relação entre a Comissão de Moradores e o FCP:

Pra mim o Fórum foi uma escola... Assim, sinceramente, o meu coração é muito grato. Ah gente... Eu agradeço tudo porque vocês não sabem a importância que foi vocês na nossa vida. Tinha vez que a gente estava aqui e o refúgio da gente era o Fórum. Tinha vez que o morro estava pegando fogo ali, quando vocês estavam lá, desabafava. Para mim, o Fórum foi, sei lá, pra mim foi muito importante. Eu não tenho nada o que falar do Fórum. Tem nossas crises? Tem. Todo mundo tem briga, mas pra mim vocês... Muitas pessoas estão dentro das casas: agradeça o Fórum também. Porque se não é o Fórum que está ali dando o sustento com a gente brigando, a gente não ia aguentar. Foi muita luta. [...] Tinha mais gente de fora do que daqui do morro. Náo era? Eram estudantes, era os apoiadores, um tanto de alunos, entáo aquilo dali era tipo... Tu não vai fazer terapia? Pobre não faz terapia. A gente não faz. Entáo era uma terapia pra gente, era uma força. Quando tu chega na casa da tua mãe: 'máe...'. Era tipo assim a casa de uma mãe que a gente se acolhia, 'gente, vamos fazer isso, vamos lá fora, vamos pegar um cartaz', então aquilo dali dava fôlego pra gente esses três anos. Pra mim o Fórum foi um fôlego, pra mim (Entrevista concedida por moradora da escadaria, em novembro de 2014).

O Fórum, no início, eu achava que era um grupo de pesquisa, de estudos acadêmicos. Quando a D. me contou, só que a primeira vista eu pensava que era defender alguma tese, alguma coisa, juntou a fome com a vontade de comer: 'eles vão nos ajudar e daqui vão [palavra incompreensível] os trabalhos deles. Depois, quando eu fui me aprofundando, eu vi que a coisa era mais séria. E realmente o pessoal estava destinado a ajudar. [...] Aquela vez que nós subimos aqui, fomos parar lá em cima no meio da chuva. Andamos para caramba. Para mim é importante, o apoio de vocês foi fundamental, até porque aquele momento ali foi único. Teve um momento em que a coisa estava muito unida, muito (Entrevista concedida por morador do Sessenta, em maio de 2014).

Como podemos notar, as declaraçôes expóem uma contradiçấo estabelecida entre distintas formas de luta no processo mais amplo da luta pelo espaço portuário que merece ser bem compreendida, não a fim de enfatizar e reforçar estigmas mútuos ou segmentaçôes, mas, sim, a fim de compreender aquilo que potencialmente é agregador e que já está presente como semente e utopia no próprio processo de produção do espaço urbano. 
É importante entender que existem novas formas de movimentação social, múltiplas, fluidas e heterogêneas, no contexto contemporâneo. Os sujeitos envolvidos nesses novos movimentos compreendem desde aqueles tidos como mais tradicionais, voltados para a construção de horizontes utópicos de transformação total das relações sociais, até sujeitos que passam a se movimentar pela necessidade urgente de preservar a vida. Quando esses sujeitos se aproximam e somam-se em um coletivo que atende a demandas mais pontuais e causas específicas, as contradiçóes afloram, sendo preciso exercitar a capacidade de trabalhar com elas a fim de resistir coletivamente a uma conjuntura que, por si só, é extremamente adversa e desagregadora.

\section{TRAZENDO AS CONTRADIÇÕES PARA A LUTA}

É importante dizer que, metodologicamente, a contradição é parte essencial do processo social analisado. Como dissemos, a pesquisa se funda no materialismo histórico e dialético e, portanto, seria incoerente tratar o processo de luta examinado de forma homogênea e/ou não contraditória. Sendo assim, este artigo se configura como uma espécie de chamado para que as diversas formas de luta sejam entendidas em suas singularidades, bem como em partes da totalidade social.

Há, desse modo, uma diferença de escala analítica. Ao olharmos para a totalidade do processo de produçáo do espaço, no escopo do Projeto Porto Maravilha, para os conflitos e resistências associados a ele, notamos, de saída, a contradição fundamental entre os sujeitos e processos hegemônicos e os sujeitos da resistência, estes últimos compreendidos como um bloco mais ou menos homogêneo. Ao aproximarmos a escala de observação - e aí somente contando com um percurso empírico de pesquisa que exigiu certo grau de envolvimento e subjetividade -, vêm à tona as contradiçóes no interior do processo de luta mais amplo, contradiçôes que se configuram na dialética com a contradição central entre dominantes e dominados. É por esse motivo que as novas formas de luta e os novos sujeitos (ou antigos sujeitos com novas roupagens) devem ser considerados em suas singularidades e particularidades, sem perder de vista a dimensão central da luta.

O que intencionamos destacar é que, no fundo, como já foi dito, trata-se de uma única luta: a luta pelo espaço. Em meio ao processo de produção do espaço urbano, o uso está sempre latente. Assim, a luta se sintetiza na construção de possibilidades de submissão da troca ao uso. Pensar na dialética do espaço é, nesse sentido, pensar na superação das contradições entre valor de uso e valor de troca. Essa superação está presente como virtualidade, e significa, efetivamente, a luta pela restituição do uso. Só é possível pensar nessa luta, por sua vez, por meio da atenção à dimensão cotidiana da vida.

A luta, para Holloway (2013), é urgente e está, portanto, presente no cotidiano, na permanente dialética entre exclusão-recusa-criação. Assim, no próprio movimento de reprodução da sociedade, movimento que busca atender à urgência e ao desespero por mudanças, são construídas fissuras. Estas estão presentes no fazer concreto que se encontra em cada uma das nossas açôes, e a forma de expansão delas passa pela construção de relaçôes horizontais que ofereçam outros modos de viver e de edificar o mundo, numa luta constante contra a verticalidade. 
Analisando a luta pelo espaço empreendida pelos grupos de moradores considerados aqui - ocupaçôes urbanas, moradores dos casarôes da Rua do Livramento e Comissão de Moradores da Providência -, é perfeitamente possível enxergar que se trata de uma luta inscrita no cotidiano, e não em espaços institucionalizados. Ademais, ela tem uma demanda específica e urgente: a permanência dos moradores em seus lugares de vida. Tal permanência está associada à própria sobrevivência das pessoas. É visível o movimento de exclusão-recusa-criação no processo analisado. Os moradores, pouco a pouco, abrem mais e mais fissuras, à medida que resistem e criam novas formas de relações sociais, que são, também, espaciais. Formar uma comissão tal como foi feito, no caso estudado, resultou na construçấo de relaçóes horizontais e solidárias entre moradores que pouco se conheciam.

Ainda, a luta evidencia a construção de um novo modo de conceber o e viver no espaço. Os moradores constroem, na luta, novas representações do espaço, em relação dialética tanto com o espaço percebido quanto com o espaço vivido. Seus sonhos, seus desejos, aquilo que não pode ser racionalizado pelo saber hegemônico, passam a povoar suas concepçóes a respeito do que deve ser o espaço urbano.

A luta se movimenta, assim, na construção de fissuras que, no horizonte, se expandidas e consideradas dentro de um projeto amplo de transformação social, podem resultar na construção de contra-espaços (LEFEBVRE, 2013 [1974]), construção progressiva que parte justamente das lutas cotidianas, mas que implica a elaboração de um projeto. Enquanto os contra-espaços não são efetivamente construídos - ainda que o sejam na dimensão das novas representaçôes do espaço, o que já é um grande passo -, é importante prestar atenção, seguindo Lefebvre, aos desvios, aos modos de ocupação reivindicativa de determinadas formas espaciais, que apontam para o fim da dominação, ao menos provisoriamente. As ocupaçôes urbanas podem ser perfeitamente interpretadas sob esse prisma, bem como a vigília realizada na Praça Américo Brum, no dia previsto para o seu fechamento.

O fato de mais de 700 casas previstas para serem derrubadas terem permanecido no Morro da Providência pode ser considerado como um exemplo de fissura? ${ }^{11}$ Seriam tais casas, por si só, fissuras, uma vez que foram construídas de forma horizontal, solidária e autônoma, comportando uma relaçấo dialética que submete o valor de troca ao valor de uso?

Esses espaços apresentam contradiçóes que são produzidas no processo histórico - contradiçóes diacrônicas que permanecem em um olhar sincrônico contemporâneo. Além disso, vivemos uma conjuntura política e econômica, em escala global e nacional, que tem acirrado o individualismo, a competição, a fragmentação e a despolitização.

Os moradores envolvidos na luta, que lutam pela sua própria sobrevivência, mas que se articulam a uma luta mais ampla, estâo imersos em um cenário altamente complexo, com múltiplas relaçôes de poder e contradiçôes que aparecem justamente quando vem à tona a contradição entre suas formas de luta, táticas, estratégias, demandas e seus objetivos e as formas de luta das organizaçóes e instituiçóes que compóem o FCP. Dessa forma, o que desejamos ressaltar aqui é aquilo que essas lutas possuem em comum, a fim de que este trabalho possa contribuir para o entendimento de que, no fundo, todos os sujeitos em questão estão buscando formas e estratégias para atingir um objetivo que é comum, objetivo que se constrói na luta pelo espaço. Enfatizamos, então, mais as aproximaçôes que os afastamentos, mais a união que a desagregação.

Frente ao grande desafio com o qual nos deparamos em relação às possibilidades
11 Devido ao tamanho do artigo, não aprofundamos essa questão. Vale mencionar que, inicialmente, das aproximadamente duas mil casas existentes na favela da Providência, 832 estavam previstas para serem removidas. Com a luta dos moradores associados ao FCP e parceiros diversos, tendo como protagonista a DPGE, esse número passou para cerca de 70 (pouco mais de cem já tinham sido removidas), o que foi novamente contestado pelos moradores e apoiadores. Para maiores detalhes, ver: Giannella (2015) e Faulhaber \& Azevedo (2015). 
de análise teórica das novas formas de mobilização social, novas formas de luta e novos (ou não tão novos assim) sujeitos, este trabalho aponta para a necessidade de encararmos tais processos a partir de démarches que considerem: (a) as diferenças de escala no processo de luta; (b) as múltiplas relaçôes de poder e a historicidade que envolve a construção delas; e (c) os diferentes sujeitos da resistência, tanto em suas singularidades, como também em suas particularidades, compreendendo-os como parte de uma luta mais ampla - a luta pelo espaço.

Tais afirmaçôes, as quais se aproximam mais de apontamentos e abertura que de conclusões e fechamento, embasam-se principalmente na nossa experiência no FCP entre 2011 e 2014, em alguns momentos com maior envolvimento e intensidade e, em outros, com maior distanciamento. Os processos de desagregação vivenciados e observados no coletivo deram origem à motivação para a compreensão mais aprofundada das lutas contemporâneas, já que não era possível conceber aquele processo por meio de leituras que desconsiderassem as contradiçôes apresentadas.

A busca por esse entendimento continua em processo e, certamente, assim permanecerá, uma vez que as dinâmicas são cada vez mais fluidas, múltiplas, contraditórias e heterogêneas. Nesse sentido, finalizamos o artigo com a transcrição de uma passagem inspiradora de John Holloway (2013, p. 246-247):

Não existe uma resposta certa, apenas milhôes de experimentos: não existe resposta certa única à desesperada (e pertinente) questão sobre o que deve ser feito. Talvez a melhor resposta que pode ser dada é: pensem por si mesmo e por si mesmos [...]. Para alguns, isso significa se atirar de cabeça nas preparaçóes para a próxima cúpula anti-G-8. Para outros, significará tentar abrir perspectivas de um mundo diferente para as crianças para quem dão aulas na escola. Outros se unirão aos seus vizinhos para criar uma horta comunitária, ou participarão das atividades do centro social próximo. Alguns dedicarão todas as suas energias para organizar a oposição à extensão da estrada que ameaça o sustento de milhares de camponeses, alguns se dedicarão à permacultura ou a criar software livre, outros simplesmente brincarão com seus filhos e amigos ou escreverão um livro sobre como mudar o mundo. Tudo isso são gritos de esperança, projeçóes em direção a uma maneira diferente de viver, tentativas de fazer algo melhor com nossas vidas do que criar o capitalismo. Talvez nem tudo tenha o mesmo impacto, mas felizmente não temos um padrão com o qual medi-los. Quem dirá que fazer parte do assim chamado black bloc em uma anticúpula do G-8 é mais ou menos efetivo como meio de luta do que criar um jardim como meio de lutar contra o massacre de outras formas de vida pelos humanos? Não existe resposta correta, única, mas isto não significa que todas essas lutas sejam atomizadas. Há uma ressonância entre elas, um reconhecimento mútuo como sendo parte de um movimento contra-e-mais-além, um constante compartilhar de ideias e informação.

\section{REFERÊNCIAS}

COMITÊ POPULAR DA COPA E OLIMPÍADAS. Dossiê Megaeventos e violaçōes dos direitos humanos no Rio de Janeiro, 2014. Rio de Janeiro: Comitê Popular da Copa e Olimpíadas, 2014. Disponível em: <http://rio.portalpopulardacopa.org.br/>. Acesso em: 15 maio 2015. DE CERTEAU, M. A invenção do cotidiano: 1. Artes de fazer. Petrópolis: Vozes, 2012 [1990].

DUARTE, R. G. O processo de reabilitaçáo e renovaçáo urbana na cidade do Rio de Janeiro 
e suas perspectivas. Scripta Nova, Barcelona, v. IX, n. 194, n.p., 2005.

FAULHABER, L.; AZEVEDO, L. SMH 2016: remoçôes no Rio de Janeiro olímpico. Rio de Janeiro: Mórula, 2015.

FOUCAULT, M. Segurança, território, população. São Paulo: Martins Fontes, 2008 [1977-1978]. - Vigiar e punir. Petrópolis: Vozes, 2010 [1975].

Microfísica do poder. Rio de Janeiro: Graal, 2011 [1979].

GIANNELLA, L. Revirando o Porto Maravilha: luta pelo espaço e contradiçóes urbanas na zona portuária do Rio de Janeiro. 2015. 309 f. Tese (Doutorado em Geografia) - Instituto de Geociências, Universidade Federal Fluminense, Niterói, 2015.

HARVEY, D. A justiça social e a cidade. São Paulo: Hucitec, 1980 [1973].

HOLLOWAY, J. Fissurar o capitalismo. São Paulo: Publisher Brasil, 2013.

LEFEBVRE, H. A re-produção das relações de produção. Porto: Escorpião, 1973. A revolução urbana. Belo Horizonte: Ed. UFMG, 2008 [1970]. La producción del espacio. Madrid: Capitain Swing, 2013 [1974].

ROLNIK, R. Apresentação - As vozes das ruas: as revoltas de junho e suas interpretaçóes. In: MARICATO, E et al. Cidades rebeldes: passe livre e as manifestaçóes que tomaram as ruas do Brasil. São Paulo: Boitempo; Carta Maior, 2013. p. 7-12.

VAINER, C. Pátria, empresa e mercadoria: notas sobre a estratégia discursiva do Planejamento Estratégico Urbano. In: ARANTES, O.; VAINER, C.; MARICATO, E. A cidade do pensamento único: desmanchando consensos. 5. ed. Petrópolis: Vozes, 2009 [2000]. p. 75-104.

ZIBECHI, R. Dispersar el poder: los movimientos como poderes antiestatales. Buenos Aires: Tinta Limón, 2006. . Autonomías y emancipaciones: América Latina en movimento. Lima: Fondo Editorial de la Facultad de Ciencias Sociales (UNMSM), 2007.

. Espacios, territorios y regiones: la creatividad social de los nuevos movimientos sociales en América Latina. Cuchará y paso atrá, n. 18, p. 95-119, 2008.

A B S T R A C T : While the Porto Maravilha's promoters work to disseminate images of an aseptic and free of conflicts city, we can observe that the conflicts has been intensified in the city of Rio de Janeiro in recent years. Within this framework, the article seeks to uncover such conflicts from the field of resistance and various forms of struggle that has been built and mobilized, especially in the scope of Fórum Comunitário do Porto, collective formed in 2011 who served in reporting rights violations in populations affected by the intervention and articulating institutions for the defense of those rights. We sought to submit to analysis the new mobilization processes, the construction of counter-powers and cracks that occur in the heart of the production of space, also identifying the internal contradictions of the struggle and pointing to the need for new theoretical approaches the could help to understand the contemporary world.

K E Y W O R D S : Porto Maravilha; Fórum Comunitário do Porto; urban conflicts; struggle for space; social movements. 